\title{
PENCAPAIAN AKADEMIK PELAJAR KURANG UPAYA PENGLIHATAN YANG MENGIKUTI PROGRAM PENDIDIKAN KHAS
}

Nur Khairul Nisha Roslan \& Haris Abd. Wahab ${ }^{1}$

\begin{abstract}
Primary objective of this study is to identify the relationship between academic achievement among the visually impaired students with their socio-demographic profiles. The study was carried out at one Special Education Secondary School for the visually impaired in Setapak, Kuala Lumpur. 83 visually handicapped students were purposively selected to be respondents of the study. Primary data was collected through face-to-face interview using a structured questionnaire. Academic achievement was assessed based on their exam result for compulsory core subjects; Malay Language, English Language, Mathematic, Science, and Islam Education or Moral Education. Academic achievement was categorized into three level; low, moderate and high. The study discovered that the academic achievement among the students was at an average level. The analysis showed that the only socio-demographic variable that has a significant relationship with the student's academic performance level was the family income.
\end{abstract}

Kata kunci: pelajar kurang upaya penglihatan, pencapaian akademik, profil sosio-demografi keluarga

\section{Pendahuluan}

${ }_{1}$ Cik Khairul Nisha merupakan Calon Sarjana, Jabatan Pentadbiran \& Keadilan Sosial, Fakulti Sastera dan Sains Sosial, Universiti Malaya. Dr Haris (haris@um.edu.my) pula adalah Profesor Madya, di Pentadbiran dan Keadilan Sosial, Fakulti Sastera dan Sains Sosial, Universiti Malaya.

Penulis Koresponden: Nur Khairul Nisha Roslan (knisha 87@yahoo.com) 
Sebanyak 10 peratus daripada jumlah penduduk Malaysia terdiri daripada golongan Orang Kurang Upaya (Buletin Perangkaan Malaysia, 2011). Perangkaan daripada Jabatan Kebajikan Masyarakat Malaysia (2013) pula menunjukkan sehingga Jun 2013 terdapat seramai 464,967 orang kurang upaya (OKU) yang berdaftar dengan Jabatan berkenaan. Daripada jumlah tersebut, seramai 42,909 orang terdiri daripada mereka yang mengalami kurang upaya penglihatan (Jadual 1).

Jadual 1: Pendaftaran Orang Kurang Upaya 2012- Jun 2013

\begin{tabular}{lcc}
\hline & \multicolumn{2}{c}{ TAHUN } \\
\cline { 2 - 3 } JENIS KECACATAN & $\mathbf{2 0 1 2}$ & $\mathbf{2 0 1 3}$ \\
Pendengaran & 53,357 & 55,517 \\
Penglihatan & 40,510 & 42,909 \\
Fizikal & 148,461 & 153,918 \\
Masalah Pembelajaran & 165,281 & 170,809 \\
Pertuturan & 1,734 & 2,725 \\
Mental & 14,990 & 16,998 \\
Lain-lain/pelbagai & 20,673 & 22,091 \\
Jumlah & 445,006 & 464,967 \\
\hline
\end{tabular}

Sumber : Jabatan Kebajikan Masyarakat, Malaysia 2013

Mereka yang dikategorikan sebagai golongan kurang upaya penglihatan ialah mereka yang terganggu visualnya; walaupun menggunakan cermin mata atau kanta sentuh (Smith, 1998). Ia termasuk mereka yang buta atau separuh buta. Kadar ketajaman penglihatan normal ini ialah 20/20. Seseorang dianggap buta apabila kadar ketajaman acuity penglihatannya adalah 20/200 atau kurang; walaupun menggunakan cermin mata atau kanta sentuh (Koestler, 1976). Mereka yang mempunyai ketajaman penglihatan antara 20/200 hingga 20/70 walaupun menggunakan cermin mata dianggap separa buta (National Society for the Prevention of Blindness, 1976).

Mengikut Encyclopedia of Special Education (1987), kurang upaya penglihatan merupakan satu istilah yang merujuk kepada mereka yang tidak mempunyai daya penglihatan. Dalam konteks pendidikan khas, mereka yang kurang upaya penglihatan belajar melalui kaedah tektual, auditori dan pengalaman estetik tanpa memerlukan daya penglihatan. 
Kirk dan Anastasiow (2000) yang membincangkan istilah kurang upaya penglihatan dari perspektif pendidikan khas mengkelasifikasikan pelajar yang mengalami masalah kurang upaya penglihatan kepada tiga kategori utama; iaitu:

1) Penglihatan sederhana yang boleh diperbetulkan dengan alat-alat penglihatan tertentu,

2) Penglihatan menyukarkan, terhad atau rabun yang boleh menggunakan alat-alat bantuan penglihatan pembelajaran; dan,

3) Penglihatan teruk yang tidak boleh menggunakan alat-alat penglihatan umtuk membantu daya penglihatan sehingga mereka yang mengalaminya perlu menggunakan deria sentuhan dan pendengaran dalam pembelajaran.

Di Malaysia, orang kurang upaya (OKU) berpeluang untuk mendapatkan pendidikan bermula dari peringkat sekolah rendah, sekolah menengah dan sehingga ke institusi pengajian tinggi sama ada di Institusi Pengajian Tinggi Awam (IPTA) mahupun di Institusi Pengajian Tinggi Swasta (IPTS). Antara program pendidikan yang disediakan oleh kerajaan untuk golongan ini ialah Program Pendidikan Khas, Program Integrasi dan Program Pemulihan Dalam Komuniti (PDK). Program pendidikan khas yang dilaksanakan bagi pelajar kurang upaya penglihatan di negara ini merupakan sebahagian daripada Dasar Pendidikan Kebangsaan.Amalan ini memperlihatkan yang hak dan peluang pelajar kurang upaya penglihatan dalam menyertai sistem pendidikan formal tidak diabaikan (Jabatan Pendidikan Khas, 2000).

Pendidikan khas di Malaysia telah mendapat perhatian semua pihak apabila Akta Pendidikan 1996 menyatakan Program Pendidikan Khas di sekolah kerajaan dan bantuan kerajaan layak diikuti oleh pelajar kurang upaya yang boleh dididik; dengan syarat dia mampu menguruskan diri sendiri tanpa bergantung kepada

bantuan orang lain dan disahkan oleh suatu panel yang terdiri daripada pengamal perubatan, pegawai daripada Kementerian Pendidikan dan pegawai daripada Jabatan Kebajikan Masyarakat sebagai berupaya mengikut Program Pendidikan Kebangsaan. 
Sehubungan dengan itu, pendidikan khas di Malaysia pada masa kini adalah di bawah tanggungjawab empat kementerian iaitu Kementerian Kesihatan, Kementerian Pembangunan Wanita, Keluarga dan Masyarakat, Kementerian Pelajaran Malaysia, Kementerian Pengajian Tinggi dan Kementerian Sumber Manusia. Kementerian Pembangunan Wanita, Keluarga dan Masyarakat bertanggungjawab menyediakan perkhidmatan kepada kanak-kanak yang cacat fizikal, terencat akal sederhana dan teruk serta kanak-kanak spastik atau terencat. Manakala, Kementerian Kesihatan pula bertanggungjawab mengenal pasti kanakkanak yang dilahirkan dalam keadaan berisiko (Jamila, 2005).

\section{Sorotan Literatur}

Sistem pendidikan negara merujuk pencapaian akademik pelajar sebagai hasil penilaian guru terhadap satu ataupun beberapa perkara yang diajar kepada pelajar menerusi pemberian markah, peratus, gred pangkat ataupun kedudukan ranking pelajar dalam kelas.

Menurut Abu Zahari (1987, maklumat pencapaian akademik pelajar boleh ditentukan semasa guru mengajar, pada aktiviti masa pembelajaran ataupun selepas satu tempoh masa pengajaran. Pencapaian pelajar dalam peperiksaan seperti Ujian Penilaian Sekolah Rendah (UPSR), Penilaian Menengah Rendah (PMR) dan Sijil Pelajaran Malaysia (SPM) pula dilaksanakan bagi menguji dan menilai kemahiran dan pengetahuan sedia ada (pre-requisite skills). Keputusan peperiksaan ini dapat menilai pencapaian pelajar sama ada berada pada tahap rendah, sederhana atau tinggi.

Pencapaian akademik lebih berfokus kepada gred yang diperolehi oleh seseorang pelajar dalam peperiksaan yang diduduki. Sekiranya seseorang pelajar itu mencapai gred yang baik bermakna mereka mencapai kecemerlangan dalam bidang akademik. Pencapaian akademik juga merujuk kepada hasil yang diperoleh oleh pelajar setelah mempelajari sesuatu ilmu pengetahuan. Secara khususnya, pencapaian akademik merujuk kepada penguasaan ilmu pengetahuan dan kemahiran pada sesuatu tahap mengikut ukuran peperiksaan. Pencapaian akademik pelajar diukur melalui tahap pencapaian mereka dalam peperiksaan terkini mengikut setiap 
mata pelajaran teras yang wajib diambil. Kerlinger (1973) mentakrifkan pencapaian akademik secara operasional melalui suatu ujian yang berasaskan penilaian guru dalam sesuatu ujian. Kecemerlangan akademik merupakan kayu ukur utama keberkesanan sekolah (Sergiovanni, 2001).

Terdapat banyak kajian terdahulu yang telah membuktikan kepentingan faktor sosio-demografi pelajar dan keluarga dalam mempengaruhi pencapaian akademik individu. Antara faktor sosio-demografi yang berpengaruh kepada pencapaian akademik pelajar ialah jantina, bangsa, latar pendidikan ibu bapa, pekerjaan ibu bapa dan pendapatan ibu bapa.

Dalam aspek jantina umpamanya, terdapat beberapa kajian lepas yang menunjukkan tahap pencapaian akademik pelajar perempuan lebih tinggi berbanding dengan pelajar lelaki (Bridegement \& Wendler, 1995). Kajian Azizi, Asmah, Zurihanmi dan Fawziah (2005) juga mendapati pelajar perempuan memperolehi pencapaian yang lebih baik berbanding dengan pelajar lelaki. Perbezaan ini berkaitan rapat dengan sikap pelajar perempuan yang lebih positif dan memberi perhatian yang lebih serius kepada kerja-kerja sekolah dan minat membaca yang lebih baik berbanding dengan pelajar lelaki (Dwyer, 1974; Fennema, 1987; Halpern, 1992; McKenna, 1997).

Sutherland (dalam Tinklin, Coxford, Frame dan Ducklin, 2000) juga menyatakan pencapaian akademik pelajar perempuan lebih baik berbanding dengan pelajar lelaki adalah suatu fenomena global. Keadaan yang sama turut berlaku di Malaysia apabila data daripada Kementerian Pendidikan Malaysia (2000) mengenai keputusan peperiksaan awam dari tahun 1996-1999 menunjukkan pelajar perempuan memperoleh prestasi akademik yang lebih baik berbanding pelajar lelaki dalam peperiksaan awam di peringkat sekolah rendah (UPSR), menengah rendah (PMR) dan menengah atas (SPM).

Bagi faktor bangsa pula, kajian Sharifah (1991) telah mendapati bahawa faktor bangsa mempunyai hubungan signifikan dengan pencapaian akademik pelajar. Kajian beliau mendapati bangsa India mempunyai hubungan yang negatif dan signifikan dengan pencapaian akademik. Berbanding kanak-kanak Melayu dan Cina, Sharifah mendapati pencapaian akademik kanak-kanak India agak rendah. 
Dalam bukunya Sociology of Learning (1972), Boocock menyatakan pengaruh-pengaruh dalam pencapaian akademik seseorang pelajar termasuklah persekitaran sosial keluarga seperti jenis keluarga, taraf pendidikan keluarga, jenis pekerjaan ibu bapa dan pendapatan keluarga. Hasil kajian oleh Anuar (1990) mendapati tahap pendidikan ibu bapa mempengaruhi secara signifikan pencapaian akademik anak-anak. Semakin tinggi tahap pendidikan ibu bapa, semakin berjaya pencapaian akademik anak. Ibu bapa yang berpelajaran tinggi bersikap liberal, terbuka serta sama-sama berganding bahu mengajar dan mengambil berat terhadap pelajaran anak-anak mereka. Penglibatan ibu bapa dalam aktiviti anak-anak dan sanggup meluangkan masa bersama anak-anak di rumah serta mengambil tahu dalam pelajaran anak-anak membawa kepada peningkatan pencapaian akademik.

Seterusnya, bagi pembolehubah pekerjaan ibu bapa, Milne et al. (1986) mengatakan status pekerjaan ibu dan jenis keluarga mempengaruhi pencapaian akademik pelajar di sekolah. Ibu tunggal yang bekerja dalam jenis pekerjaan berpendapatan rendah memberi kesan negatif dalam pencapaian pelajaran anakanak. Kesan ini bergantung pula kepada umur ibu, ras ibu, struktur keluarga, pendapatan dan masa yang diluangkan untuk pendidikan anak-anak. Kajian Mohd Noor dan Mohd Meerah (1988) menunjukkan pencapaian dalam bacaan Bahasa Melayu berbeza dalam kalangan pelajar daripada keluarga bertaraf sosioekonomi tinggi, sederhana dan rendah. Pelajar daripada status sosioekonomi tinggi memperolehi pencapaian dalam bacaan lebih tinggi daripada pelajar yang berstatus sosioekonomi rendah.

\section{Metodologi Kajian}

Kajian ini bertujuan untuk mengenal pasti tahap pencapaian akademik pelajar kurang upaya penglihatan yang mengikuti Program Pendidikan Khas (Special Education Programme). Kajian tinjauan ini telah dijalankan di sebuah sekolah Pendidikan Khas untuk pelajar kurang upaya penglihatan, Setapak, Kuala Lumpur. Seramai 83 orang pelajar kurang upaya penglihatan telah dipilih secara bertujuan (purposive sampling) sebagai responden. Mereka terdiri daripada pelajar tingkatan 1 hingga 4 sahaja. Latar belakang demografi responden diringkaskan dalam Jadual 2. 
Jadual 2: Maklumat Latar Belakang Demografi Responden

\begin{tabular}{lcc}
\hline Maklumat Demografi & $\begin{array}{c}\text { Bilangan } \\
(\mathbf{n})\end{array}$ & $\begin{array}{c}\text { Peratusan } \\
(\%)\end{array}$ \\
\hline Jantina & & \\
Lelaki & 38 & 45.8 \\
$\quad$ Perempuan & 45 & 54.2 \\
\hline Jumlah & 83 & 100.0 \\
\hline Umur & & \\
13-14 tahun & 24 & 28.9 \\
$15-16$ tahun & 47 & 56.6 \\
$17-18$ tahun & 12 & 14.5 \\
\hline Jumlah & 83 & 100.0 \\
\hline Bangsa & & \\
Melayu & & 80.7 \\
Cina & 67 & 10.8 \\
India & 9 & 8.5 \\
\hline Jumlah & 7 & 100.0 \\
\hline Jenis penglihatan & 83 & \\
Buta & & 44.6 \\
Rabun & 37 & 55.4 \\
\hline Jumlah & 46 & 100.0 \\
\hline Bahan bacaan & 83 & 48.2 \\
Braille & & 51.8 \\
Biasa & 40 & 100.0 \\
\hline Jumlah & 43 & \\
\hline
\end{tabular}

Manakala, maklumat latar belakang sosioekonomi responden adalah tahap pendidikan bapa dan ibu, pekerjaan bapa dan ibu serta pendapatan keluarga (Jadual 3). Maklumat kajian ini diperoleh melalui temu bual secara bersemuka menggunakan borang soal selidik dan dianalisis menggunakan perisian komputer Statistical Package for the Social Science (SPSS). Maklumat dibentang dalam bentuk taburan bilangan dan peratusan. 
Jadual 3: Maklumat Latar Belakang Sosioekonomi Responden

\begin{tabular}{|c|c|c|}
\hline Maklumat sosioekonomi & $\begin{array}{c}\text { Bilangan } \\
(\mathbf{n}) \\
\end{array}$ & $\begin{array}{c}\text { Peratusan } \\
(\%)\end{array}$ \\
\hline \multicolumn{3}{|l|}{ Pendidikan bapa } \\
\hline Sekolah Rendah & 3 & 3.6 \\
\hline Sekolah Menengah Rendah & 15 & 18.1 \\
\hline Sekolah Menengah Atas & 35 & 42.2 \\
\hline Kolej/Universiti & 30 & 36.1 \\
\hline Jumlah & 83 & 100.0 \\
\hline \multicolumn{3}{|l|}{ Pendidikan ibu } \\
\hline Sekolah Rendah & 4 & 4.8 \\
\hline Sekolah Menengah Rendah & 13 & 15.7 \\
\hline Sekolah Menengah Atas & 32 & 38.6 \\
\hline Kolej/Universiti & 34 & 40.9 \\
\hline Jumlah & 83 & 100.0 \\
\hline \multicolumn{3}{|l|}{ Pekerjaan bapa } \\
\hline Kerajaan & 28 & 33.7 \\
\hline Swasta & 21 & 25.3 \\
\hline Bekerja sendiri & 33 & 39.8 \\
\hline Bersara & 1 & 1.2 \\
\hline Jumlah & 83 & 100.0 \\
\hline \multirow{6}{*}{\multicolumn{3}{|c|}{$\begin{array}{l}\text { Pekerjaan ibu } \\
\text { Kerajaan } \\
\text { Swasta } \\
\text { Bekerja sendiri } \\
\text { Bersara } \\
\text { Tidak bekerja }\end{array}$}} \\
\hline & & \\
\hline & & \\
\hline & & \\
\hline & & \\
\hline & & \\
\hline Jumlah & 83 & 100.0 \\
\hline \multicolumn{3}{|l|}{ Pendapatan ibu bapa } \\
\hline RM500-RM1000 & 15 & 18.1 \\
\hline RM1001-RM2000 & 21 & 25.3 \\
\hline RM2001-RM3000 & 19 & 22.9 \\
\hline RM3001-RM4000 & 16 & 19.3 \\
\hline RM4001-RM5000 & 10 & 12.0 \\
\hline RM5000 ke atas & 2 & 2.4 \\
\hline Jumlah & 83 & 100 \\
\hline
\end{tabular}

Pencapaian akademik pelajar kurang upaya penglihatan diperoleh berdasarkan gred yang dicapai oleh pelajar bagi subjek Bahasa Melayu, Bahasa Inggeris, Matematik, Sains, Sejarah dan Pendidikan Islam atau Pendidikan Moral dalam peperiksaan terkahir yang mereka duduki. Manakala, penentuan tahap pencapaian akademik pelajar kurang upaya penglihatan ditentukan berdasarkan skor pemarkatan yang diperoleh bagi enam subjek berkenaan (Jadual 4). 
Jadual 4: Skala Pemarkatan Pencapaian Akademik

\begin{tabular}{cc}
\hline Gred Mata Pelajaran & Skor Markah \\
\hline A & 5 \\
B & 4 \\
C & 3 \\
D & 2 \\
E & 1 \\
F & 0 \\
\hline
\end{tabular}

\section{Hasil Kajian Dan Perbincangan}

\section{Pencapaian Akademik Pelajar Kurang Upaya Penglihatan}

Bahagian ini membincangkan taburan bilangan dan peratusan gred pemarkahan bagi setiap matapelajaran teras yang ditawarkan di sekolah menengah pendidikan khas cacat penglihatan (Jadual 5). Antara matapelajaran teras yang diukur adalah subjek Bahasa Melayu, Bahasa Inggeris, Matematik, Sains, Sejarah dan Pendidikan Islam atau Pendidikan Moral.

Jadual 5: Pencapaian Akademik Pelajar Mengikut Gred Pencapaian

\begin{tabular}{lcccccc}
\hline & \multicolumn{6}{c}{ Gred Pemarkahan (N =83) } \\
\cline { 2 - 7 } & $\mathbf{A}$ & $\mathbf{B}$ & $\mathbf{C}$ & $\mathbf{D}$ & $\mathbf{E}$ & $\mathbf{F}$ \\
Bahasa Melayu & 27 & 31 & 21 & 4 & & 0 \\
Bahasa English & $(32.5 \%)$ & $(37.3 \%)$ & $(25.3 \%)$ & $(4.8 \%)$ & $(0.0 \%)$ & 0 \\
& 0 & 3 & 19 & 29 & 20 & 12 \\
Matematik & $(0.0 \%)$ & $(3.6 \%)$ & $(22.9 \%)$ & $(34.9 \%)$ & $(24.1 \%)$ & $(14.5)$ \\
& 3 & 14 & 24 & 30 & 8 & 4 \\
Sains & $(3.6 \%)$ & $(16.9 \%)$ & $(28.9 \%)$ & $(36.1 \%)$ & $(9.6 \%)$ & $(4.8 \%)$ \\
& 5 & 12 & 30 & 24 & 8 & 7 \\
Sejarah & $(6.0 \%)$ & $(14.5 \%)$ & $(36.1 \%)$ & $(25.3 \%)$ & $(9.6 \%)$ & $(8.4 \%)$ \\
& 7 & 24 & 18 & 23 & 6 & 5 \\
Pendidikan Islam/ & $(8.4 \%)$ & $(28.9 \%)$ & $(21.7 \%)$ & $(27.7 \%)$ & $(7.2 \%)$ & $(6.0 \%)$ \\
Pendidikan moral & $(24.1 \%)$ & 25 & 30 & 8 & 0 & 0 \\
\hline & & $(30.1 \%)$ & $(36.1 \%)$ & $(9.6 \%)$ & $(0.0 \%)$ & $(0.0 \%)$ \\
\hline
\end{tabular}

Penemuan kajian menunjukkan majoriti iaitu seramai 31 orang (37.3\%) pelajar kurang upaya penglihatan memperoleh gred B bagi subjek Bahasa Melayu. Pelajar yang mendapat gred A bagi subjek Bahasa Melayu adalah seramai 27 orang (32.5\%). Kajian ini juga mendapati tidak ada seorang pun pelajar yang gagal bagi subjek Bahasa Melayu. Segelintir sahaja iaitu seramai 4 orang (4.8\%) pelajar kurang upaya penglihatan yang memperoleh gred D bagi subjek Bahasa Melayu. 
Bagi subjek Bahasa Inggeris pula, majoritinya (seramai 29 orang atau $34.9 \%)$ responden kajian ini mendapat gred D. Tidak ada seorang pun pelajar kurang upaya penglihatan yang mendapat gred A bagi subjek Bahasa Inggeris. Hanya segelintir sahaja iaitu seramai 3 orang (3.6\%) yang mendapat gred B. Walau bagaimanapun, penemuan kajian mendapati ramai juga pelajar kurang upaya penglihatan yang gagal bagi subjek ini. Seramai 20 orang (24.1\%) responden mendapat gred $\mathrm{E}$ dan gred $\mathrm{F}$ pula seramai 12 orang (14.5\%).

Kajian ini mendapati 30 orang (36.1\%) pelajar kurang upaya penglihatan mendapat gred D bagi subjek matematik. Namun, hanya segelintir sahaja iaitu seramai 3 orang (3.6\%) pelajar kurang upaya penglihatan memperoleh gred A. Walau bagaimanapun, terdapat juga segelintir pelajar kurang upaya penglihatan yang gagal yang memperoleh gred $\mathrm{F}$ dalam subjek matematik iaitu seramai 4 orang $(4.8 \%)$.

Bagi subjek Sains pula, penemuan kajian menunjukkan majoriti pelajar kurang upaya penglihatan memperoleh gred C iaitu seramai 30 orang (36.1\%). Kemudian, penemuan kajian mendapati terdapat juga sebilangan kecil pelajar kurang upaya penglihatan yang memperoleh gred A iaitu seramai 5 orang (6.0\%). Walau bagaimanapun, terdapat sebilangan kecil juga pelajar kurang upaya penglihatan yang gagal dalam subjek sains iaitu memperoleh gred F seramai 7 orang $(8.4 \%)$.

Seterusnya, penemuan kajian mendapati paling ramai pelajar kurang upaya penglihatan memperoleh gred B bagi subjek Sejarah iaitu seramai 24 orang (28.9\%). Kemudian, sebilangan kecil sahaja iaitu seramai 7 orang (8.4\%) pelajar yang memperoleh gred A bagi subjek Sejarah. Namun, terdapat segelintir daripada pelajar kurang upaya penglihatan yang gagal dalam subjek Sejarah iaitu memperoleh gred $\mathrm{F}$ seramai 5 orang (6.0\%).

Bagi subjek Pendidikan Islam (pelajar muslim) Atau Pendidikan Moral (pelajar bukan muslim), penemuan kajian menunjukkan majoriti iaitu seramai 30 orang (36.1\%) pelajar kurang upaya penglihatan mendapat gred C. Walau bagaimanapun, terdapat juga sebilangan kecil iaitu seramai 20 orang (24.1\%) yang mendapat gred A. Namun, penemuan kajian mendapati tidak ada seorang pun 
pelajar kurang upaya penglihatan sama ada pelajar muslim atau pelajar bukan muslim yang gagal bagi subjek Pendidikan Islam atau Pendidikan Moral.

\section{Tahap Pencapaian Akademik Pelajar Kurang Upaya Penglihatan}

Bahagian ini membincangkan mengenai tahap pencapaian akademik pelajar kurang upaya penglihatan (Jadual 6). Penentuan tahap pencapaian akademik ditentukan berdasarkan skor yang diberikan kepada setiap subjek; iaitu $\mathrm{A}=5, \mathrm{~B}=4, \mathrm{C}=3, \mathrm{D}$ $=2, \mathrm{E}=1$ dan $\mathrm{F}=0$. Kemudian, tahap pencapaian akademik pelajar kurang upaya penglihatan dikategorikan kepada tiga tahap pencapaian iaitu rendah, sederhana dan tinggi.

Penentuan sela skor tahap pencapaian akademik pelajar kurang upaya penglihatan adalah berdasarkan nilai purata gred pemarkahan dan dibahagikan dengan 6 subjek teras melalui arahan compute variable dan sisihan piawai. Tahap pencapaian akademik yang rendah ditentukan dengan cara purata skor ditolak dengan nilai sisihan piawai. Tahap pencapaian akademik yang sederhana adalah nilai skor antara tahap yang rendah dan tahap yang tinggi. Kemudian, tahap pencapaian akademik yang tinggi pula ditentukan dengan cara purata skor ditambah dengan nilai sisihan piawai.

Dalam kajian ini, skor purata yang diperoleh ialah 2.9, dan nilai sisihan piawai ialah 0.8. Skor yang kurang daripada 2.1 menunjukkan tahap pencapaian akademik pelajar kurang upaya penglihatan adalah rendah. Kemudian, skor antara 2.2 hingga 3.6 menunjukkan tahap pencapaian akademik pelajar kurang upaya penglihatan adalah sederhana dan skor 3.7 dan ke atas pula menunjukkan tahap pencapaian akademik pelajar kurang upaya penglihatan adalah tinggi.

Berdasarkan Jadual 6, penemuan kajian menunjukkan sebilangan besar iaitu seramai 58 orang (69.9\%) pelajar kurang upaya penglihatan yang menyertai kajian ini memperoleh tahap pencapaian akademik yang sederhana. Kemudian, terdapat juga sebilangan kecil iaitu seramai 15 orang (18.1\%) yang memperoleh tahap pencapaian akademik yang tinggi dan selebihnya seramai 10 orang (12.0\%) pelajar kurang upaya penglihatan berada pada tahap pencapaian akademik yang rendah. 
Jadual 6: Tahap Pencapaian Akademik Pelajar Kurang Upaya Penglihatan

\begin{tabular}{lccc}
\hline & \multicolumn{1}{c}{ Tahap } & Bil & \% \\
\hline Rendah & $($ Skor $\leq 2.1)$ & 10 & 12.0 \\
Sederhana & $($ Skor $2.2-3.6)$ & 58 & 69.9 \\
Tinggi & ( Skor $\geq 3.7)$ & 15 & 18.1 \\
\hline Jumlah & & 83 & 100.0 \\
\hline
\end{tabular}

Skor Purata $=2.9 ;$ Skor Minima $=1.3 ;$ Sisihan Piawai $=0.8 ; \quad$ Skor Maksima $=4.7$

Oleh itu, secara keseluruhannya tahap pencapaian akademik pelajar kurang upaya penglihatan yang mengikuti program pendidikan khas di sekolah Pendidikan Khas di mana kajian ini dilakukan berada pada tahap pencapaian akademik yang sederhana. Penemuan kajian ini disokong dengan hasil kajian lepas yang menyatakan kebanyakan pelajar kurang upaya (OKU) memperolehi pencapaian akademik yang sederhana dan rendah dan sering dikaitkan dengan tidak produktif, tidak bekerjasama dan kurang aktif (Wallace dan Kauffman, 1996).

Kajian Gargiulo (2003), Easterbooks dan Baker (2002) dan Moores (2001) juga mendapati hal yang sama. Kebanyakan pelajar kurang upaya menunjukkan pencapaian akademik yang sederhana. Dapatan kajian ini berbeza daripada dapatan yang diperoleh sejak tahun 1954, yang menunjukkan tahap pencapaian akademik pelajar kurang upaya di Malaysia adalah berbentuk turun naik dan masih berada pada tahap yang lama (Jamila, 2005).

\section{Hubungan Antara Latar Belakang Pelajar Dengan Pencapaian Akademik}

Bahagian ini membincangkan hasil analisis ujian khi kuasa dua untuk melihat hubungan di antara latar belakang demografi dan sosioekonomi dengan tahap pencapaian akademik pelajar kurang upaya penglihatan. 
Jadual 7 : Hubungan Antara Latar Belakang Demografi Dengan Pencapaian

Akademik

\begin{tabular}{cccccc}
\hline & \multicolumn{4}{c}{ Tahap Pencapaian Akademik } & \\
\cline { 2 - 4 } $\begin{array}{c}\text { Latar Belakang } \\
\text { Demografi }\end{array}$ & $\begin{array}{c}\text { Rendah } \\
(\mathrm{n}=10)\end{array}$ & $\begin{array}{c}\text { Sederhana } \\
(\mathrm{n}=58)\end{array}$ & $\begin{array}{c}\text { Tinggi } \\
(\mathrm{n}=15)\end{array}$ & $\begin{array}{c}\text { Keseluruhan } \\
(\mathrm{n}=83)\end{array}$ & $\mathbf{d k}$
\end{tabular}

Jantina

\begin{tabular}{lcccccc} 
Lelaki & 40.0 & 50.0 & 33.3 & 28.9 & 1.487 & 2 \\
Perempuan & 60.0 & 50.0 & 66.7 & 56.6 & & \\
\hline Jumlah & 100.0 & 100.0 & 100.0 & 100.0 & & \\
\hline & & & & & & \\
Umur & & & & & & \\
$13-14$ tahun & 40.0 & 27.6 & 26.7 & 28.9 & & \\
$15-16$ tahun & 40.0 & 62.1 & 46.7 & 56.6 & 4 \\
$17-18$ tahun & 20.0 & 10.3 & 26.7 & 14.5 & & \\
\hline Jumlah & 100.0 & 100.0 & 100.0 & $100 . .0$ & & \\
\hline
\end{tabular}

Bangsa

\begin{tabular}{lcccccc} 
Melayu & 100.0 & 77.6 & 80.0 & 80.7 & & \\
Cina & 0.0 & 12.1 & 13.3 & 10.8 & 2.933 & 4 \\
India & 0.0 & 10.3 & 6.7 & 8.4 & & \\
\hline Jumlah & 100.0 & 100.0 & 100.0 & 100.0 & \\
\hline
\end{tabular}

Jenis Kecacatan

\begin{tabular}{lcccccc} 
Buta & 20.0 & 48.3 & 46.7 & 44.6 & 2.793 & 2 \\
Rabun & 80.0 & 51.7 & 53.3 & 55.4 & & \\
\hline Jumlah & 100.0 & 100.0 & 100.0 & 100.0 & \\
\hline
\end{tabular}

Bahan Bacaan

\begin{tabular}{lcccccc} 
Braille & 30.0 & 51.7 & 46.7 & 48.2 & 1.629 & 2 \\
Biasa & 70.0 & 48.3 & 53.3 & 51.8 & & \\
\hline Jumlah & 100.0 & 100.0 & 100.0 & 100.0 & \\
\hline
\end{tabular}

Nota: $* \mathrm{P}<0.05,{ }^{*} * \mathrm{P}<0.01, * * * \mathrm{P}<0.001$

Tahap pencapaian akademik pelajar kurang upaya penglihatan dalam kajian ini diukur melalui 3 tahap pencapaian iaitu tahap rendah, tahap sederhana dan tinggi. Maklumat latar belakang demografi yang diteliti adalah umur, jantina, bangsa, jenis kecacatan dan bahan bacaan. Manakala latar belakang sosioekonomi meliputi aspek tahap pendidikan ibu bapa, pekerjaan ibu bapa dan pendapatan keluarga pelajar kurang upaya penglihatan. Dari Jadual 7, hasil analisis ujian Khi Kuasa Dua menunjukkan tidak terdapat perbezaan yang signifikan dari segi pencapaian akademik mengikut kategori umur, jantina, bangsa, jenis kecacatan dan bahan bacaan $(\mathrm{P}>$ 0.05). Hasil analisis Ujian Khi Kuasa Dua juga menunjukkan 
tidak terdapat perbezaan yang signifikan dari segi pencapaian akademik mengikut kategori tahap pendidikan ibu dan bapa, pekerjaan ibu dan bapa pelajar kurang upaya penglihatan $(\mathrm{P}>0.05)$.

Walau bagaimanapun, analisis tersebut menunjukkan terdapat perkaitan yang signifikan di antara tahap pendapatan keluarga dengan pencapaian akademik pelajar kurang upaya penglihatan $(\mathrm{P}<0.05)$. Penemuan ini menunjukkan bahawa semakin tinggi pendapatan pendapatan sesebuah keluarga akan menyumbang kepada pencapaian akademik yang lebih baik dalam kalangan pelajar kurang upaya penglihatan (Jadual 8).

Tahap pendapatan ibu bapa seringkali ditonjolkan sebagai satu pembolehubah penting yang mempengaruhi kejayaan pencapaian akademik pelajar. Ramai mempercayai bahawa pelajar dari keluarga berada selalu menunjukkan pencapaian yang lebih baik dari para pelajar yang datang dari keluarga yang mempunyai taraf pendapatan yang rendah. Ini adalah kerana keluarga yang mempunyai taraf pendapatan yang tinggi mampu menyediakan kemudahankemudahan yang mencukupi kepada anak mereka, yang seterusnya menyumbang kepada sikap, motivasi, keyakinan diri dan pencapaian yang memuaskan.

Kajian Razali (1985) menyatakan keluarga yang berada selalu dikaitkan dengan sikap yang optimis, harapan yang tinggi, kurang kebimbangan dan berfikiran terbuka. Sementara keluarga yang berpendapatan rendah pula dicirikan sebagai mempunyai sikap yang pesimis, harapan yang rendah dan tidak berfikiran terbuka. 
Jadual 8: Hubungan Antara Latar Belakang Sosioekonomi Dengan Pencapaian Akademik

\begin{tabular}{|c|c|c|c|c|c|c|}
\hline \multirow[b]{2}{*}{ Latar Belakang } & \multicolumn{4}{|c|}{ Tahap Pencapaian Akademik } & \multirow[b]{2}{*}{$\mathbf{x}^{2}$} & \multirow[b]{2}{*}{ dk } \\
\hline & $\begin{array}{c}\text { Renda } \\
h \\
(n=10 \\
)\end{array}$ & $\begin{array}{c}\text { Sederhan } \\
\text { a } \\
(n=58)\end{array}$ & $\begin{array}{c}\text { Tingg } \\
\text { i } \\
(n=15)\end{array}$ & $\begin{array}{l}\text { Keseluruh } \\
\text { an }(n=83)\end{array}$ & & \\
\hline \multicolumn{7}{|l|}{ Pendidikan Bapa } \\
\hline Sekolah Rendah & 0.0 & 0.0 & 6.7 & 1.2 & \multirow{4}{*}{8.496} & \multirow{4}{*}{6} \\
\hline MenengahRendah & 40.0 & 48.3 & 20.0 & 42.2 & & \\
\hline Menengah Atas & 40.0 & 31.0 & 53.3 & 36.1 & & \\
\hline Kolej / Universiti & 20.0 & 20.7 & 20.0 & 20.5 & & \\
\hline Jumlah & 100.0 & 100.0 & 100.0 & 100.0 & & \multirow{7}{*}{6} \\
\hline \multicolumn{7}{|l|}{ Pendidikan Ibu } \\
\hline Sekolah Rendah & 10.0 & 0.0 & 6.7 & 2.4 & \multirow{6}{*}{10.281} & \\
\hline Menengah & 60.0 & 34.5 & 40.0 & 38.6 & & \\
\hline \multicolumn{5}{|l|}{ Rendah } & & \\
\hline Menengah Atas & 10.0 & 48.3 & 46.7 & 43.4 & & \\
\hline Kolej / Universiti & 20.0 & 17.2 & 6.7 & 15.7 & & \\
\hline Jumlah & 100.0 & 100.0 & 100.0 & 100.0 & & \\
\hline Pekerjaan Bapa & & & & & \multirow{5}{*}{9.280} & \multirow{5}{*}{8} \\
\hline Kerajaan & 50.0 & 27.6 & 46.7 & 33.7 & & \\
\hline Swasta & 30.0 & 27.6 & 13.3 & 25.3 & & \\
\hline Bekerja Sendiri & 20.0 & 44.8 & 33.3 & 39.8 & & \\
\hline Bersara & 0.0 & 0.0 & 6.7 & 1.2 & & \\
\hline Jumlah & 100.0 & 100.0 & 100.0 & 100.0 & & \\
\hline \multicolumn{7}{|l|}{ Pekerjaan Ibu } \\
\hline Kerajaan & 10.0 & 19.0 & 40.0 & 21.7 & \multirow{5}{*}{10.611} & \multirow{5}{*}{8} \\
\hline Swasta & 10.0 & 32.8 & 20.0 & 27.7 & & \\
\hline Bekerja Sendiri & 10.0 & 10.3 & 20.0 & 12.0 & & \\
\hline Bersara & 0.0 & 1.7 & 0.0 & 1.2 & & \\
\hline Tidak Bekerja & 70.0 & 36.2 & 20.0 & 37.4 & & \\
\hline Jumlah & 100.0 & 100.0 & 100.0 & 100.0 & & \\
\hline \multicolumn{7}{|l|}{ Pendapatan keluarga } \\
\hline RM500-RM1000 & 10.0 & 19.0 & 20.0 & 18.1 & \multirow{6}{*}{$\begin{array}{c}32.735^{* * *} \\
*\end{array}$} & \multirow{6}{*}{10} \\
\hline RM1001-RM2000 & 50.0 & 25.9 & 6.7 & 25.3 & & \\
\hline RM2001-RM3000 & 10.0 & 31.0 & 0.0 & 22.9 & & \\
\hline RM3001-RM4000 & 30.0 & 17.2 & 20.0 & 19.3 & & \\
\hline RM4001-RM5000 & 0.0 & 6.9 & 40.0 & 12.0 & & \\
\hline RM5000 ke atas & 0.0 & 0.0 & 13.3 & 2.4 & & \\
\hline Jumlah & 100.0 & 100.0 & 100.0 & 100.0 & & \\
\hline
\end{tabular}

Penemuan kajian ini juga disokong dengan kajian lepas yang menunjukkan bahawa pelajar daripada keluarga berpendapatan tinggi menikmati persekitaran pembelajaran yang menggalakkan. Dalam tahun-tahun 2000 dan ke atas terdapat 
ahli Sosiologi yang mengkaji isu pencapaian dalam pendidikan dan kaitannya dengan pendapatan keluarga. Misalnya, Orr dalam Black-White Differences in Achievement-The Importance of Wealth (2003) menyatakan kekayaan sebagai:

\begin{abstract}
"As a form of economic capital, then wealth can be used as both a direct financial resource and can be converted into other types of capital, either cultural or social. Wealth, as economic capital, can help parents to purchase many important educational resources, such as books, computers, private schooling, and various status symbols. Wealth can also be cashed in or converted to give the next generations some degree of cultural, as well as social, capital (for example, by allowing parents to spend more time with their children). The presence of various forms of capital can contribute positively to a child's achievement."
\end{abstract}

(Orr 2003: 282).

Beliau mengatakan kekayaan boleh mempengaruhi pencapaian akademik secara positif. Ibu bapa yang mempunyai pendapatan yang kukuh kurang mendapat masalah dalam melancarkan anak-anak mencapai pelajaran ke peringkat yang lebih tinggi. Dengan kata lain, pelajar daripada status sosioekonomi tinggi mendapat pencapaian akademik yang lebih baik berbanding dengan pelajar daripada berstatus sosioekonomi rendah dan sederhana. Keluarga yang berada mempunyai peluangpeluang yang lebih untuk membeli bahan pendidikan atau mengadakan kelas bimbingan tambahan. Oleh itu, persekitaran pembelajaran yang lebih baik boleh diadakan apabila pendapatan keluarga tinggi.

Begitu juga kajian oleh Luster dan McAdoo (1991) ke atas anak-anak di Afrika dan Amerika. Mereka mendapati pendapatan keluarga mempunyai perkaitan yang positif dan signifikan dengan pencapaian akademik anak. Keluarga yang kurang berkemampuan menghadapi masalah untuk membeli peralatan dan bahan pembelajaran, membayar yuran sekolah, tambang bas, dan membeli cermin mata. Pelajar dari keluarga berpendapatan tinggi mempunyai kecenderungan untuk mempunyai aspirasi tinggi, ekspektasi tinggi dan pencapaian akademik tinggi. Keluarga yang berpendidikan dan berpendapatan tinggi mampu mengadakan persekitaran belajar yang sesuai dan baik.

Alvarez (1989) menyatakan "Family income correlates moderately with achievement in mathematihcs" (hal. 82). Manakala, keluarga yang kurang 
berkemampuan menghadapi masalah untuk membeli peralatan dan bahan pembelajaran, membayar yuran sekolah, tambang bas, dan membeli cermin mata (BPPDP, 1996).

Marimuthu (1996) menyatakan taraf sosio ekonomi dan pencapaian akademik menunjukkan hubungan yang positif iaitu semakin tinggi taraf sosioekonomi ibu bapanya, maka tinggilah pencapaian akademik kanak-kanak itu. Ini menjelaskan sebaliknya akan berlaku jika status sosio ekonomi ibu bapa itu adalah rendah.

Selain itu, Menurut Noraini (dalam Zukina Yusoff, 2003) anak-anak daripada keluarga yang mempunyai status sosioekonomi yang tinggi adalah lebih maju dalam pendidikan dan mempunyai gred yang tinggi berbanding anak-anak yang datang daripada keluarga yang mempunyai status sosioekonomi yang rendah. Ini kerana dalam keadaan status sosial yang tinggi, ibu bapa dapat menyediakan kemudahan dan persekitaran pembelajaran yang selesa kepada anak-anak mereka. Ibu bapa yang berstatus tinggi mampu menyediakan keperluan pendidikan sejak dari kanak-kanak lagi. Ini membolehkan anak-anak mereka lebih berjaya dan berpeluang masuk ke IPT sedangkan mereka yang tidak mampu terlepas peluang. Peluang untuk mendapat pendidikan tinggi memerlukan sejumlah kos yang agak banyak. Pelajar dari kelas sosioekonomi yang tinggi memperolehi purata pencapaian yang tinggi berbanding dengan pelajar dari keluarga yang berstatus sosioekonomi rendah.

\section{Penutup}

Dapatan kajian menunjukkan faktor sosioekonomi terutamanya tahap pendapatan ibu bapa mempunyai perkaitan yang sangat kuat terhadap pencapaian akademik pelajar kurang upaya penglihatan. Peningkatan pencapaian akademik pelajar kurang upaya penglihatan adalah usaha bersama ke arah pendidikan bertaraf dunia yang seterusnya akan dapat merealisasikan wawasan 2020. Setiap pelajar di negara kita mempunyai peluang yang sama untuk mendapat pendidikan tidak mengira umur, jantina ataupun bangsa. Dasar pendidikan Negara yang inginkan pelajarnya maju dari segi intelek, rohani, jasmani, emosi dan sosial perlu menitikberatkan supaya 
pelajar dapat mengembangkan potensi diri mereka. Terdapat segolongan pelajar yang dilabelkan sebagai orang kurang upaya (OKU). Pelajar ini sebenarnya juga mempunyai keistimewaan seperti pelajar yang lain, tetapi mereka sering dianggap lemah, mundur dan lembap. Pelajar seperti ini sepatutnya perlu diberi perhatian dan galakan supaya mereka dapat memberi sumbangan kepada negara sebagaimana pelajar normal yang lain. Justeru itu, pelajar kurang upaya (OKU) ini harus diberi pengagihan sumber pendidikan yang sama seperti yang diberikan kepada pelajar normal.

Kesimpulannya, diharapkan bahawa matlamat falsafah pendidikan khas seperti mana yang digariskan oleh Jabatan Pendidikan Khas (JPK) iaitu pendidikan khas di Malaysia adalah satu usaha yang berterusan untuk melahirkan insan yang berkemahiran, berhaluan, berupaya, beriman, berdikari, mampu merancang dan menguruskan kehidupan serta menyedari potensi diri sendiri sebagai seorang individu dan ahli masyarakat yang seimbang dan produktif selaras dengan falsafah pendidikan negara dapat dicapai melalui tiga program pendidikan khas utama iaitu program pendidikan di sekolah khas, program pendidikan percantuman, dan program pendidikan inklusif.

\section{Rujukan}

Abu Zahari Abu Bakar. (1987). Memahami Psikologi Pembelajaran. Petaling Jaya: Fajar Bakti Sdn. Bhd.

Alvarez, A. (1989). Correlation of personal, home background and intermediate variables with cognitive achievement in mathematics, English, Malay and general paper of primary six Bruneian students. Sultan Hassanal Bolkiah Institute of Education, Universiti Brunei Darussalam.

Anuar Abdullah. (1990). Perkaitan Di Antara Latar Belakang Dan Konsep Kendiri Pelajar Dengan Pencapaian Akademik. Projek sarjana yang tidak diterbitkan. Serdang: Universiti Putra Malaysia.

Asiah Hj. Ahmad. (2012). Mengenal dan menangani orang kurang upaya. Kuala Lumpur: Dewan Bahasa dan Pustaka.

Azizi Yahaya; Asmah Suboh; Zurihanmi Zakaria; Fawziah Yahya. (2005). Aplikasi Kognitif dalam Pendidikan. Kuala Lumpur: PTS Professional Publishing. Kuala Lumpur. 
Boocock, S. (1972). An introduction to the sociology of learning. Boston:Houghton Mifflin Company.

Bridgeman, B dan Wendler, C. (1995). Gender differences in predictors of college mathematics course grades. Journal of Educational Psychology. 83, 275-284.

Buletin Perangkaan Malaysia. (2013). Jabatan Perangkaan Malaysia.

Dwyer, C. A. (1974). Influence of children's sex role standards on reading and mathematics achievement. Journal of Educational Psychology. 66, 811-816.

Fennema, E. (1980). Sex-related Differences in Mathematics Achievement: Where and Why. Dlm L. H. Fox, L. Brody, \& D. Tobin, (Ed.). Women and the Mathematical Mystique. Baltimore: John Hopkins University Press.

Hallahan, D.P. dan \& Kauffman, J.M. (1986). Exceptional Children: Introduction to Special Education (Edisi Ke-3). New Jersey: Prentice Hall.

Halpern, D. F. (1992). Sex Differences in Cognitive Abilities. Hillsdale, NJ: Erlbaum.

Jamila K. A. Mohamed. (2005). Pendidikan Khas Untuk Kanak-kanak Istimewa. Kuala Lumpur : PTS Professional Publishing Sdn.Bhd.

JKMM [Jabatan Kebajikan Masyarakat Malaysia]. (2013). Profail Statistic 2013. Kuala Lumpur: Jabatan Kebajikan Masyarakat Malaysia.

Kauffman. J. M. (1993). How We Might Achieve The Radical Reform Of Special Education. Exceptional Children, 60 (1), 6-16.

Kementerian Pendidikan Malaysia. (2000). Perangkaan Pendidikan Malaysia 2000. KL: Kementerian Pendidikan Malaysia.

Kerlinger, F. N. (1973). Foundations of Behavioral Research. New York: Holt, Rinehart and Winston.

Kirk, S.A. (1972). Educating Exceptional Children. Boston: Houghton Mifflin Company.

Luster, T. \& McAdoo, H.O. (1991). Factors related to the achievement and adjustment of young African-American children. Department of Family and Child Ecology, Michigan State University.

Marimuthu. (1996). Pengenalan Sosiologi Pendidikan. Shah Alam: Fajar Bakti.

McKenna, E. 1997. Gender Differences in Reading Attitudes. ERIC Document No:ED407653

Milne A.M. (1986). Single parents, working mothers, and the educational achievement of school children. Sociology of Education. 59 (July),125-139.

Mohd Noor A. \& Mohd Meerah S. (1988). Masalah kenal huruf. Monograf, Fakulti Pendidikan, Universiti Kebangsaan Malaysia. 
Orr, A.J. (2003). Black-white differences in achievement: the importance of wealth. Sociology of Education, 76 (October), 281-304.

Razali Arof. (1985). Rural Students and Academic Performance: A Case Study Of Program Matrikulasi University Kebangsaan Malaysia. Unpublished Doctoral Dissertation. Cornell University.

Sergiovanni, T. J. (2001). The Principalship: A Reflective Practice Perspective. Texas: Allyn and Bacon.

Smith, T. E. C., Poloway, E. A., Patton, J. R. \& Dowdy, C. A. (1995) Teaching students with special needs. Boston: Ally and Bacon.

Sharifah Mohd Noor. (1991). Faktor-faktor latar belakang yang berkaitan dengan pencapaian akademik murid darjah satu. Jurnal Pendidik dan Pendidikan. Jilid 11, 1991/92, 61-69.

Stockard, J \& Wood, J. K. (1984). The myth of female underachievement: a reexamination of sex differences in academic underachievement. American Education Research Journal. 21 , 4.

Tinklin, T., Croxford, L. Frame, B., \& Ducklin, A. (2000). Gender and Pupil Performance in Scotland. Kertas Kerja. The European Conference on Educational Research, Edinburgh. Available online: http:www//leeds.ac.uk/educol/documents/ o0001663.htm

Zukina Yusoff. (2003). Hubungan antara Latar Belakang Keluarga dengan Pencapaian Akademik Pelajar Melayu dalam PMR. Masters thesis, Universiti Utara Malaysia. 